\title{
ANALISIS EFEKTIVITAS, EFISIENSI PAJAK DAERAH DAN RETRIBUSI DAERAH SERTA KONTRIBUSI TERHADAP PENDAPATAN ASLI DAERAH DI KABUPATEN BANTUL TAHUN 2009-2014
}

\author{
Ryfal Yoduke* \\ Sri Ayem \\ Program Studi Akuntansi Fakultas Ekonomi \\ Universitas Sarjanawiyata Tamansiswa Yogyakarta \\ *mioevettyoduke@gmail.com
}

\begin{abstract}
The study was conducted in Bantul, for research purposesprovides an overview of (1) the effectiveness of the tax year dearah to PAD2009-2014; (2) efficiency at local levies to PAD 20092014; (3)Local Tax contribution to PAD for 2009-2014;(4) contribution levies Area to PAD 20092014.The nature of the research include descriptive, population is the report Bantul year's actual revenue and budget realization report service producer Retribution 2009-2014, also at the same till. Method Data collection is a method of secondary data, as well as techniques to analyze the data using the ratio of effectiveness, efficiency ratio, and the ratio of contribution. The study found that the level of effectiveness of the Local Tax 2009, 2011, 2012, 2013, 2014, very effective, and in 2010 effective. Level Retribution efficiency 2009-2014, entirely exceeded 100\% andotherwise very ineffective. Local Tax contribution in 2009 at the level ofless; In 2010, 2011, 2014 moderate; 2012 and 2013 is quite good. Contributions Retribution 2009 at a very good level, 2010-2013 criteria is less,2014 is very less.
\end{abstract}

Keywords: Effectiveness and Efficiency, Contributions, Local Taxes and Levies, PAD

\section{PENDAHULUAN}

Meningkatnya volume pembangunan dari tahun ke tahun dan ditambah dengan naiknya populasi penduduk dan kebutuhan hidup merupakan masalah dan beban pembangunan yang patut dicermati, upaya pemecahan masalah dan beban pembangunan tersebut menuntut peran pemerintah secara berkesinambungan. Dalam prakteknya, pemerintah pusat memiliki kemampuan dari sisi memobilisasi dana pembangunan melalui sumber-sumber penerimaan negara, sedangkan pemerintah daerah dihadapkan pada masalah keterbatasan sumber-sumber penerimaan sehingga pembiayaan daerah masih bergantung pada pemerintah pusat. Tekad pemerintah untuk mewujudkan otonomi yang nyata dan bertanggung jawab melalui pemberian kewenangan yang lebih besar terhadap daerah merupakan salah satu cara untuk memberdayakan potensi daerah di berbagai bidang pembangunan, salah satu kebijakan pemerintah untuk menunjang ekonomi daerah adalah dengan mengeluarkan Undang-undang Nomor 18 Tahun 1997 tentang Pajak Daerah dan Retribusi Daerah sebagaimana telah diubah dengan Undang-undang Nomor 34 Tahun 2000 dan terakhir diubah dengan Undang-undang Nomor 28 Tahun 2009 (Undang-undang selanjutnya disebut dengan UU dan Nomor disebut dengan No.)

Menurut UU No.32 Tahun 2004 tentang Pemerintahan Daerah pada bab 5 paragraf kedua pasal 157 menjelaskan tentang Pendapatan, Belanja, dan Pembiayaan. Komponen sumber pendapatan keuangan pemerintah daerah adalah terdiri atas:

a. pendapatan asli daerah yang selanjutnya disebut PAD, yaitu:

1) hasil pajak daerah;

2) hasil retribusi daerah;

3) hasil pengelolaan kekayaan daerah yang dipisahkan; dan

4) lain-lain PAD yang sah;

b. dana perimbangan; dan

c. lain-lain pendapatan daerah yang sah. 
Pada UU No. 33 Tahun 2004 tentang Dana Perimbangan Pemerintah Pusat dan Daerah Bab I Pasal 1 ayat 18 menyebutkanPendapatan Asli Daerah, adalah pendapatan yang diperoleh Daerah yangdipungut berdasarkan Peraturan Daerah sesuai dengan peraturan perundang-undangan. Selanjutnya pada Bab IV Pasal 5 merinci penjelasan tentang sumber penerimaan daerah sebagai berikut : (1) Penerimaan Daerah dalam pelaksanaan Desentralisasi terdiri atas Pendapatan Daerah dan Pembiayaan; (2) Pendapatan Daerah sebagaimana dimaksud pada ayat (1) bersumber dari: (a). Pendapatan Asli Daerah; (b) Dana Perimbangan; dan (c) Lainlain Pendapatan. (3) Pembiayaan sebagaimana dimaksud pada ayat (1) bersumber dari: (a) sisa lebih perhitungan anggaran Daerah; (b) penerimaan Pinjaman Daerah; (c) Dana Cadangan Daerah; dan (d) hasil penjualan kekayaan Daerah yang dipisahkan. Pasal 6 ayat 1 di UU tersebut merinci bagian-bagian yang termasuk dalam PAD bersumber dari: (a) Pajak Daerah; (b) Retribusi Daerah; (c) hasil pengelolaan kekayaan Daerah yang dipisahkan; dan (d) lain-lain PAD yang sah.

Pemerintah daerah sebagai hasil implikasi sistem otonomi daerah menetapkan Anggaran Pendapatan dan Belanja Daerah (APBD) melalui Peraturan Daerah (Perda). Perda tentang APBD selalu memuat ringkasan tentang PAD beserta target yang harus dicapai dalam satu tahun berjalan (tahun kalender). Berdasarkan UU No. 32 dan 33 Tahun 2004 kemudian di perjelas pada UU No. 28 Tahun 2009 tentang Pajak Daerah dan Retribusi Daerah bab 1 pasal 10 menjelaskan bahwa Pajak Daerah, yang selanjutnya disebut Pajak, adalah kontribusi wajib kepada Daerah yang terutang oleh orang pribadi atau badan yang bersifat memaksa berdasarkan Undang-Undang, dengan tidak mendapatkan imbalan secara langsung dan digunakan untuk keperluan Daerah bagi sebesar-besarnya kemakmuran rakyat; kemudian pada pasal 64 menyebutkan bahwa Retribusi Daerah, yang selanjutnya disebut Retribusi,adalah pungutan Daerah sebagai pembayaran atas jasaatau pemberian izin tertentu yang khusus disediakandan/atau diberikan oleh Pemerintah Daerah untukkepentingan orang pribadi atau Badan.

Pajak Daerah merupakan salah satu sumber pandapatan asli yang lazim didaerah kabupaten/kota terdiri dari Pajak Hotel, Pajak Restoran, Pajak Hiburan, Pajak Reklame, Pajak Penerangan Jalan, Pajak Mineral bukan Logam dan Batuan, Pajak Parkir, Pajak Air Tanah, Pajak Sarang Burung Walet, Pajak Bumi dan Bangunan Pedesaan dan Perkotaan, Bea Perolehan Hak atas Tanah dan Bangunan, sedangkan Retribusi Daerah adalah pungutan daerah sebagai pembayaran atas jasa atau pemberian izin tertentu yang khusus disediakan dan/atau diberikan oleh pemerintah daerah untuk kepentingan orang pribadi atau badan (Yani 2009:63dikutip dari Prameka, 2012).

Penjelasan komponen Retribusi Daerah berdasarkan UU No. 28 Tahun 2009 adalah Retribusi Jasa Umum : Pelayanan kesehatan, Pelayanan kebersihan, Penggantian beban cetak KTP dan beban cetak akta catatan sipil, Pelayanan pemakaman dan pengabuan mayat, Pelayanan parkir ditepi jalan, Pelayanan pasar, Pengujian kendaraan bermotor, Pemerikasaan alat pemadam, Penggantian beban cetak peta, Penyediaan dan atau penyedotan kakus, Pengelolaan limbah cair, Pelayanan tera/tera ulang, Pelayanan pendidikan, Pengendalian menara telekomunikasi; Retribusi Jasa Usaha : Pemakaian kekayaan daerah, Jasa usaha pasar grosir atau pertokoan, Jasa usaha tempat pelelangan, Jasa usaha terminal, Jasa usaha tempat khusus parkir, Jasa usaha tempat penginapan/pesanggrahan/villa, Jasa usaha rumah potong hewan, Jasa usaha pelayanan pelabuhan, Jasa usaha tempat rekreasi dan olahraga, Penyebrangan di air, Jasa usaha penjualan produksi usaha daerah; Jasa Izin Tertentu : Izin mendirikan bangunan, Izin tempat penjualan minuman beralkohol, Izin gangguan Izin trayek, Izin usaha perikanan.

Penetapan tarif retribusi daerah ditentukan sebagai berikut : (1) tarif retribusi jasa umum ditetapkan berdasarkan kebijakan daerah dengan mempertimbangkan biaya penyediaan jasa yang bersangkutan, kemampuan masyarakat, dan aspek keadilan; (2) Sesuai dengan UU No. 28 Tahun 2009 pasal 153, prinsip dan sasaran dalam penetapan tarif 
retribusi jasa usaha didasarkan pada tujuan untuk memperoleh keuntungan yang layak; dan (3) Tarif retribusi perizinan tertentu diterapkan berdasarkan pada tujuan untuk menutupi sebagian atau seluruh biaya penyelenggaraan pemberian izin yang bersangkutan.

Menurut Mikha (2010) Pajak Daerah dan Retribusi Daerah merupakan komponen PAD, memiliki prospek yang baik untuk dikembangkan. Oleh karena itu Pajak Daerah dan Retribusi Daerah harus dikelola secara profesional dan transparan dan dalam rangka optimalisasi serta usaha meningkatkan kontribusinya terhadap PAD. Sidik (2002) melalui penelitian tentang optimalisasi Pajak Daerah dan Retribusi Daerah dalam rangka meningkatkan kemampuan keuangan daerah mengemukakan bahwa Pajak Daerah dan Retribusi Daerah merupakan komponen PAD yang seharusnya menjadi komponen penerimaan utama bagi daerah, sehingga ketergantungan daerah kepada pemerintah pusat (Dana Perimbangan) semakin berkurang dan daerah diharapkan memiliki akuntabilitas yang tinggi kepada masyarakat lokal.

Dari penguraian beberapa kutipan penelitian sebelumnya, dapat simpulkan bahwa Pajak Daerah adalah komponen PAD yang diperoleh daerah dari masyarakat sebagai suatu kewajiban tanpa adanya janji penerimaan (pengembalian) manfaat kembali secara langsung oleh masyarakat dari daerah. Retribusi Daerah menurut simpulan penulis adalah kewenangan daerah untuk menarik imbalan dari masyarakat atau orang pribadi atau badan yang memerlukan palayanan dan memperoleh serta menerima jasa dan/atau prestasi dan/atau manfaat tertentu sebagai hasil timbal-balik dari imbalan yang dibayarkan masyarakat atau orang pribadi atau badan oleh daerah.

Pemungutan Pajak Daerah dan Retribusi Daerah tidak lepas dari efektivitas dan efisiensi serta kontribusi terhadap PAD. Efektivitas adalah tingkat angka pencapaian pemerintah dalam memungut atau menarik Pajak Daerah dan Retribusi Daerah yang dibandingkan dengan target yang telah ditentukan sebelumnya. Efektivitas adalah keberhasilan atau kegagalan dari organisasi dalam mencapai tujuannya (Puspitasari, 2014). Efisiensi adalah biaya yang dipakai pemerintah daerah dalam memberikan pelayanan jasa dengan tujuan mendapatkan keuntungan layak pada proses pemungutan Pajak Daerah dan Retribusi Daerah yang kemudian dibandingkan dengan jumlah keuntungan keseluruhan, serta perbandingan bersama target. Kontribusi adalah angka yang diberikan oleh Pajak Daerah dan Retribusi Daerah terhadap jumlah keseluruhan pada angka PAD yang dicapai maupun angka pada target yang ditetapkan.

Analisis efektivitas pajak daerah yaitu analisis yang menggambarkan kemampuan pemerintah daerah dalam merealisasikan PAD yang direncanakan dibandingkan dengan target yang ditetapkan berdasarkan potensi riil daerah (Halim, 2004: 135 dalam Octovido dkk, 2014). Rasio Efektivitas menurut Handoko (2013) adalah rasio yang menggambarkan kemampuan pemerintah daerah dalam merealisasikan PAD yang didapatkan dibandingkan dengan anggaran yang ditetapkan berdasarkan potensi riil daerah, semakin tinggi rasio efektivitas, maka semakin baik kinerja pemerintah. Analisis kontribusi merupakan rasio PAD dalam $t$ tahun dengan penerimaan daerah pada tahun yang sama. Analisis kontribusi digunakan untuk mengetahui seberapa besar peranan seluruh penerimaan daerah (Pajak Daerah dan Retribusi Daerah) dalam meningkatkan $\mathrm{PAD}$, sehingga dengan adanya data tersebut dapat memberikan gambaran yang jelas mengenai tindakan atau kebijakan yang harus dilakukan pemerintah daerah dalam usaha meingkatkan peran seluruh penerimaan daerah tersebut (Mikha, 2010).

Kabupaten Bantul adalah salah satu pemerintah daerah yang menyelenggarakan UU No. 28 Tahun 2009 tentang Pajak Daerah dan Retribusi Daerah sebagai sumber PAD untuk membiayai proses operasional pemerintahan di daerah, dimana proses tersebut membutuhkan dukungan sumber daya finansial yang cukup besar. Sumber daya finansial tersebut dapat diperoleh melalui PAD yang tergolong dalam empat komponen besar yaitu (1) Pajak Daerah, (2) Retribusi Daerah, (3) Hasil pengelolaan kekayaan daerah yang dipisahkan, dan (4) Lainlain PAD yang sah. Kaitannya dengan perumusan dan penerapan komponen PAD dalam hal ini Pajak Daerah dan Retribusi 
Daerah sebagai komponen dengan potensi yang cukup besar diharapkan mampu memberikan kontribusi yang optimal.

Pajak Daerah dan Retribusi Daerah merupakan hal yang menarik untuk diteliti karena pajak daerah dan retribusi daerah cenderung menunjukan hasil fluktuatif, selain itu juga merupakan sumber pendapatan daerah yang penting guna membiayai penyelenggaraan daerah dan pembangunan daerah untuk menjalankan Otonomi Daerah. Sebagai salah kawasan pembentuk kota "besar" Yogyakarta, Kabupaten Bantul bersama Kota Yogyakarta dan Kabupaten Sleman bersama-sama membangun serta mengembangkan daerahnya masing-masing, namun demikan terlihat secara jelas bahwa Kabupaten Bantul lamban dalam pembangunan dari Kota Yogyakarta dan Kabupaten Sleman sehingga terjadi ketimpangan dalam hal pembangunan tersebut. Kelambanan yang mengakibatkan ketimpangan pembangunan tersebut menjadi satu hal yang menarik bagi penulis untuk meneliti kondisi keuangan pemerintah daerah Kabupaten bantul dari segi PAD (Pajak Daerah dan Retribusi Daerah), menganalisis efektivitas dan efisiensi penerimaan pajak daerah dan retribusi daerah di Kabupaten Bantul, kemudian seberapa besar kontribusinya terhadap PAD Kabupaten Bantul itu sendiri. Berdasarkan latar belakang masalah yang telah diuraikan tersebut serta merujuk pada penelitian oleh Julastiana dan Suartana (2013), Rosa (2012), Aryani (2015), Tope dan Darmawan (2014), Safitri (2008), Hakim (2013),Puspitasari (2014), Bahri F(2011), dan Doru (2014),dengan melakukan penyesuaian yang dibutuhkan, maka peneliti tertarik untuk mengangkat kedalam penelitian yang berjudul "Analisis Efektivitas, Efisiensi Pajak Daerah Dan Retribusi Daerah Serta Kontribusi Terhadap Pendapatan Asli Daerah Di Kabupaten Bantul Tahun 2009-2014" dengan menganalisa hal berikut :

1. Bagaimana tingkat efektivitasdan efisiensi pencapaian pemerolehan Pajak Dearah di Kabupaten Bantul tahun 2009-2014 sudah efektif?

2. Bagaimana tingkat efektivitas dan efisien pencapaian pemerolehan Retribusi Dearah di Kabupaten Bantul tahun 2009-2014 sudah efisien?

3. Tingkat kontribusi Pajak Daerah terhadap Pendapatan Asli Daerah di Kabupaten Bantul tahun 2009-2014?

4. Tingkat kontribusi Retribusi Daerah terhadap Pendapatan Asli Daerah di Kabupaten Bantul tahun 2009-2014?

\section{METODOLOGI PENELITIAN \\ Jenis Penelitian}

Jenis penelitian yang akan digunakan dalam penelitian ini adalah metode penelitian deskriptif dengan menerapkan perhitungan rasio efektivitas dan rasio efisiensi serta rasio kontribusi. Metode deskriptif ialah metode bagi peneliti untuk mendeskripsikan, menggambarkan, setra melukiskan penemuan yang terjadi dari penelitian yang dilakukan (Ardhiansyah dkk, 2014), penemuan tersebut dapat berupa perbandingan dominan antara Pajak Daerah dan Retribusi Daerah terhadap PAD. Secara keseluruhan dari penguraian teori diatas dapat dikatakan bahwa pelitian deskriptif adalah penelitian yang bertujuan untuk memetakan penerapan unsur/sumber untuk memperoleh informasi tentang proses dan hasil dari penerapan tersebut.

\section{Definisi Operasional Variabel Pendapatan Asli Daerah}

Sari (2014) menyatakan bahwa PAD merupakan pendapatan yang diperoleh daerah yang dipungut berdasarkan peratuan daerah sesuai dengan peraturan perundang-undangan, PAD merupakan salah satu indikator yang menentukan kemadirian suatu daerah. Lalityasari dkk (2013) menyimpulkan semakin besar pendapatan suatu daerah maka semakin besar pula kampuan daerah untuk menyelenggarakan usaha-usahanya atau dengan kata lain pemerintah mampu memberikan pelayanan umum kepada masyarakat. Secara Keseluruhan PAD bisa disimpulkan sebagai salah satu sumber finansial daerah yang dibutuhkan pemerintah daerah dalam melaksanakan pembangunan dan pelayanan yang diperoleh dari pemanfaatan potensi atau kekayaan dan sumber daya dari daerah itu sendiri. 


\section{Efektivitas Pajak Daerah}

Efektivitas adalah keberhasilan atau kegagalan dari organisasi dalam mencapai tujuannya. Efektivitas Pajak Daerah menunjukkan kemampuan pemerintah daerahdalam mengumpulkan pajak daerah sesuai dengan jumlah penerimaan pajak daerah yang ditargetkan(Puspitasari, 2014). Julastiana dan Suartana (2013), mengatakan upaya yang dapat dilakukan oleh pemerintah daerah untuk meningkatkan PAD yaitu dengan meningkatkan efisiensi dan efektivitas sumber-sumber pendapatan yang berpotensi meningkatkan PAD, seperti Pajak Daerah dan Retribusi Daerah.

\section{Efisiensi Pajak Daerah}

Efisiensi pajak daerah adalah nilai yang dihitung berdasarkan presentase biaya pemungutan pajak dibagi realisasi penerimaan pajak daerah (Puspitasari, 2014). Analisis pertumbuhan serta efektivitas dan efisiensi Pajak Daerah oleh Aryani (2015) menyatakan dalam kaitannya dengang pemungutan sumber pendapatan daerah khususnya pajak daerah, efisiensi biaya pengeluaran dapat diartikan efisien yang ukuran masukannya sudah tertentu yaitu biaya atau pengeluaran untuk pemungutan Pajak Daerah sedangkan keluarannya dapat diukur dengan keberhasilan penerimaan Pajak Daerah.

\section{Efektivitas Retribusi Daerah}

Efektivitas retribusi daerah merupakan perbandingan antara realisasi dan target penerimaan retribusi daerah, sehingga dapat digunakan sebagai ukuran keberhasilan dalam melakukan pungutan (Puspitasari, 2014). Untuk menganalisis kinerja administrasi Retribusi Daerah, perlu dihitung efektivitas pemungutan efektivitas Retribusi Daerah, dimana secara umum efektivitas memperlihatkan seberapa besar pendapatan retribusi dibandingkan dengan potensi Retribusi Daerah sebenarnya. Target retribusi yaitu suatu jumlah yang telah ditentukan dan harus dicapai selama setahun anggaran dan potensi penerimaan retribusi yaitu usaha untuk menaikan retribusi untuk mencapai target (Rosa, 2012).

\section{Efisiensi Retribusi Daerah}

Kata efisien berasal dari bahasa latin efficere yang berarti menghasilkan, mengadakan, menjadikan. Efisiensi Retribusi Daerah mengukur besarnya biaya pemungutan yang digunakan terhadap realisasi penerimaan retribusi itu sendiri (Puspitasari, 2014). Efisiensi Retribusi Daerah digunakan untuk mengukur bagian dari hasil Retribusiyang digunakan untuk menutup seluruh biaya yang dikeluarkan dalam rangka pengelolaan Retribusi Daerah, apabila perhitungan angka efisiensi menghasilkan angka yang kecil dari suatu pokok target/pencapaian maka suatu komponen dari terget/pencapaian (Pajak Daerah/Retribusi Daerah) yang diperoleh memiliki nilai efesiensi yang baik.

\section{Kontribusi Pajak Daerah dan Retribusi Daerah}

Kontribusi menurut Handoko (2013) bahwa kontribusi adalah analisi yang digunakan untuk mengetahui seberapa besar kontribusi yang dapat disumbangkan dari penerimaan Pajak Daerah dan Retribusi Daerah terhadap PAD, maka dibandingkan dengan realisasi penerimaan Pajak Daerah dan Retribusi Daerah terhadap PAD. Kontribusi Pajak Daerah dan Retribusi Daerah adalah kemampuan dua unsur tersebut yang mampu dipungut dan ditarik dari masyarakat oleh pemerintah daerah sebagai sumberdaya pembiayaan finansial dalam operasional pemerintahan daerah melaui PAD.

\section{Populasi dan Sampel}

Populasi adalah wilayah generalisasi yang terdiri atas objek/subjek yang mempunyai kualitas dan karateristik tertentu yang ditetapkan oleh peneliti untuk dipelajari dan kemudian ditarik kesimpulannya (Sugiono dalam Nugroho, 2014). Populasi yang ditetapkan dalam penelitian ini adalah Laporan Daftar Target dan Realisasi Pendapatan, Rincian Laporan Realisasi Anggaran Menurut Urusan Pemerintahan Daerah, Organisasi Pendapatan dan Belanja Daerah, tahun 2009-2014.

Sampel penelitian adalah sebagian atau seluruh dari jumlah populasi yang diambil untuk diuji guna menemukan dan menyimpulkan penelitian. Teknik pengambilan sampel pada penelitian ini adalah metode sensus sampling 
(Sampel jenuh) yaitu semua populasi digunakan segabai sampel (Nugroho, 2014). Sampel yang digunakan adalah seluruh populasi yang ditetapkan oleh peneliti yaitu Laporan Daftar Target dan Realisasi Pendapatan, Rincian Laporan Realisasi Anggaran Menurut Urusan Pemerintahan Daerah, Organisasi Pendapatan dan Belanja Daerah, tahun 2009-2014.

\section{Sumber Data dan Metode Pengumpulan Data}

Sumber data yang digunakan adalah sumber data sekunder, pengumpulan data menggunakan metedo runtun waktu (time series). Metode runtun waktu adalah melihat pengukuran dari waktu ke waktu tertentu, pengukuran dapat dilihat dari berbagai cara frekuensi, presentase, atau dengan cara melihat pusat kecenderungan dari suatu gejala atau kejadian (Riduansyah, 2003). Pengertian dari Mikha (2010) data sekunder adalah data yang diperoleh dalam bentuk sudah dipublikasikan, dapat berupa catatan atau laporan keuangan pemerintah daerah serta data terkait dengan penelitian. Data yang akan diteliti dalam penelitian ini adalah yaitu Laporan Realisasi Anggaran atau Laporan Akuntabilitas Kinerja Instansi Pemerintah Kabupaten Bantul atau laporan lain yang dianggap berkaitan dengan variabel yang diteliti dan dapat memberikan informasi yang dibutuhkan dengan rentang waktu 2009-2014.

\section{Metode Analisis Data}

Dalam penelitian ini, peneliti akan dengan menerapkan perhitungan rasio efektivitas Pajak Daerah untuk menghitung tingkat efektivitas, rasio efisiensi untuk menghitung tingkat efisiensi Retribusi Daerah, dan rasio kontribusi untuk menghitung kontribusi Pajak Pajak Daerah dan Retribusi Daerah.

\section{Rasio Kontribusi}

Menurut Halim dalam Fauziah dkk (2014) mengatakan bahwa kontribusi adalah sumbangan atau sesuatu kegiatan yang diberikan terhadap suatu kegiatan sehingga memberikan dampak yang bisa dirasakan. Mulyanto dalam Mikha (2010) mengatakan analisi kontribusi Pajak Daerah dan Retribusi Daerah digunakan untuk mengetahui jumlah kontribsui yang berikan terhadap PAD. Rumus yang digunakan untuk mengetahui kontribusi Pajak Daerah dan Retribusi Daerah terhadap PAD Kabupaten Bantul adalah sebagai berikut (Hakim, 2013) :

$\begin{aligned} & \text { Kontribusi } \\ & \text { Pajak Daerah }\end{aligned}=\frac{\text { Realisasi Pajak Daerah }}{\text { Realisasi PAD }} \times 100 \%$

$\begin{aligned} & \text { Kontirbusi } \\ & \text { Retribusi Daerah }\end{aligned}=\frac{\text { Retribusi Daerah }}{\text { Realisasi PAD }} \times 100 \%$

Tabel 1. Kriteria Kontribusi per Pajak

Daerah Dan Retribusi Daerah per PAD

Presentase Kontribusi Kriteria

$\begin{array}{cc}0,00 \%-10 \% & \text { Sangat Kurang } \\ 10,10 \%-20 \% & \text { Kurang } \\ 20,10 \%-30 \% & \text { Sedang } \\ 30,10 \%-40 \% & \text { Cukup Baik } \\ 40,10 \%-50 \% & \text { Baik } \\ >50 \% & \text { Sangat Baik }\end{array}$

Sumber : (Hakim, 2013)

\section{Rasio Efektivitas Pendapatan Daerah}

Rasio efektivitas menggambarkan kemampuan pemerintah daerah dalam merealisasikan PAD dalam hal ini Pajak Daerah dan Retribusi Daerah yang direncanakan dibandingkan dengan target yang ditetapkan berdasarkan potensi rill daerah. Rasio tersebut dituliskan sebagai berikut (Hakim, 2013) :

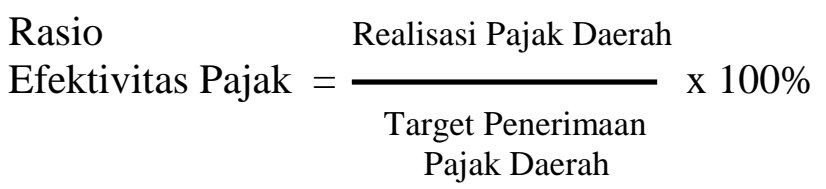


Tabel 2. Kriteria Rasio Efektivitas per Pajak Daerah dan Retribusi Daerah

$\begin{array}{cc}\text { Rasio Efektivitas } & \text { Kriteria } \\ >100 \% & \text { Sangat Efektif } \\ >90 \%-100 \% & \text { Efektif } \\ >80 \%-90 \% & \text { Cukup Efektif } \\ >60 \%-80 \% & \text { Kurang efektif } \\ <60 \% & \text { Tidak Efektif }\end{array}$

Sumber : Hakim (2013)

\section{Rasio Efisiensi Pendapatan Daerah}

Rasio Efisiensi menggambarkan efisiensi pengeluaran biaya dalam merealisasikan PAD yang direncanakan dibandingkan dengan target yang ditetapkan berdasarkan potensi rill. Perhitungan rasio ini akan diterapkan dalam perhitungan terhadap Pajak Daerah dan Retribusi Daerah. Rasio efektivitas dan rasio efisiensi dirumuskan sebagai berikut (Hakim, 2013) :

$$
\text { B. Pen. Retribusi Daerah* }
$$

Rasio Efisiensi $=\longrightarrow \times 100 \%$

Penerimaan Retribusi Daerah

*Biaya Penerimaan Retribusi Daerah

Tabel 3. Kriteria Rasio Efisiensi per Pajak Daerah dan Retribusi Daerah

\begin{tabular}{cc} 
Rasio Efisiensi & Kriteria \\
\hline$>100 \%$ & Tidak Efisien \\
$>90 \%-100 \%$ & Kurang Efisien \\
$>80 \%-90 \%$ & Cukup Efisien \\
$>60 \%-80 \%$ & Efisien \\
$<60 \%$ & Sangat Efisien
\end{tabular}

Sumber : (Hakim, 2013)
Tabel 4. Laporan Realisasi Pajak Daerah Kabupaten Bantul 2009-2014

\begin{tabular}{ccc}
\hline Tahun & $\begin{array}{c}\text { Terget Pajak } \\
\text { Daerah }\end{array}$ & Realisasi \\
\hline 2009 & 14.036 .000 .000 & 14.108 .451 .478 \\
2010 & 16.679 .578 .000 & 16.541 .249 .955 \\
2011 & 30.802 .000 .000 & 35.068 .591 .776 \\
2012 & 39.922 .684 .800 & 51.768 .352 .231 \\
2013 & 64.487 .000 .000 & 83.232 .017 .500 \\
2014 & 77.892 .200 .000 & 99.558 .470 .705
\end{tabular}

Sumber : DPPKAD Kab. Bantul, data diolah

\section{HASIL PENELITIAN DAN PEMBAHASAN Data Penelitian}

Data penelitian adalah data yang diperoleh dari dinas pendapatan, pengelolaan keuangan dan aset daerah Kabupaten Bantul yang kemudian dihitung menggunakan rasio efektivitas dan rasio kontribusi Pajak Daerah terhadap PAD, rasio efektivitas dan rasio kontribusi Retribusi Daerah PAD, serta efisiensi terhadap penerimaan Retribusi Daerah Kabupaten Bantul untuk menjawab rumusan masalah. Perhitungan efisiensi menggukan data belanja langsung, belanja tidak langsung, dan belanja operasional dinas-dinas penghasil Retribusi Daerah Kabupaten Bantul.

\section{Analisis Data Rasio Efektivitas Pajak Daerah}

Analisis Efektivitas adalah tingkat angka pencapaian pemerintah dalam memungut atau menarik Pajak Daerah dan Retribusi Daerah yang dibandingkan dengan target yang telah ditentukan sebelumnya. Efektivitas adalah keberhasilan atau kegagalan dari organisasi dalam mencapai tujuannya(Puspitasari, 2014). Data yang diperoleh dari Dinas Pendapatan, Pengelolaan Keuangan dan Aset Daerah Kabupaten Bantul dengan rentang waktu yang diteliti adalah 2009-2014, dengan menerapkan perhitungan rumus rasio efektivitas maka diperoleh gambaran tentang tingkat kefektivan pemungutan pajak daerah, perhitungan rasio tersebut adalah sebagai berikut : 
JURNAL AKUNTANSI VOL.3 NO.2 DESEMBER 2015

Tabel 5. Target dan Realisasi Pajak Daerah Kabupaten Bantul(dalam rupiah)

\begin{tabular}{ccc}
\hline Tahun & Target & Reaslisasi \\
\hline 2009 & 14.036 .000 .000 & 14.108 .451 .478 \\
2010 & 16.679 .578 .000 & 16.541 .249 .955 \\
2011 & 30.802 .000 .000 & 35.068 .591 .776 \\
2012 & 39.922 .684 .800 & 51.768 .352 .231
\end{tabular}

$$
\begin{array}{lll}
2013 & 64.487 .000 .000 & 83.232 .017 .500 \\
2014 & 77.892 .200 .000 & 99.558 .470 .705
\end{array}
$$

Sumber : DPPKAD Kab. Bantul, data diolah

Rumus :

Rasio Efektivitas Pajak $=\frac{\text { Realisasi Pajak Daerah }}{\text { Target Penerimaan Pajak Daerah }} \times 100 \%$

Tabel 6. Perhitungan Efektivitas Pajak Daerah Kabupaten BantulPeriode 2009-2014 (dalam rupiah)

\begin{tabular}{cccrl}
\hline Tahun & Target & Reaslisasi & Efektivitas & \multicolumn{1}{c}{ Kriteria } \\
\hline 2009 & 14.036 .000 .000 & 14.108 .451 .478 & $100,56 \%$ & Sangat Efektif \\
2010 & 16.679 .578 .000 & 16.541 .249 .955 & $99,17 \%$ & Efektif \\
2011 & 30.802 .000 .000 & 35.068 .591 .776 & $113,85 \%$ & Sangat Efektif \\
2012 & 39.922 .684 .800 & 51.768 .352 .231 & $129,67 \%$ & SangatEfektif \\
2013 & 64.487 .000 .000 & 83.232 .017 .500 & $129,06 \%$ & Sangat Efektif \\
2014 & 77.892 .200 .000 & 99.558 .470 .705 & $127,81 \%$ & Sangat Efektif \\
\hline
\end{tabular}

Sumber : DPPKAD Kab. Bantul, data diolah

Perhitungan rasio atas target dan realisasi serta penjelasan tabel 5 dan tabel 6 memperlihatkan tren pencapaian pemungutan pajak. Tingkat efektivitas diatas dapat menjelaskan bahwa pada tahun 2009 tingkat perolehan Pajak Daerah memenuhi kriteria sangat efektif dengan angka 100,56\%; pada tahun 2010 menjelaskan keadaan yang menurun yakni hanya memenuhi tingkat kriteria efektif sebesar 99,17\%; tahun 2011 kembali menunjukan tren positif dengan meningkatnya tingkat efektivitas dari tahun sebelumnya ke angka $113,85 \%$ dengan kriteria sangat efektif; tahun 2012 memberikan informasi pencapaian yang naik sebesar $15,82 \%$ yakni sebesar $129,67 \%$ memenuhi kriteria sangat efektif; tahun 2013 mengalami penurunan $0,61 \%$ dari angka $129,67 \%$ ke angka $129,06 \%$ tetapi tetap memenuhi kriteria sangat efektif; dan pada tahun 2014, tingkat perolehan Pajak Daerah oleh pemerintah daerah kembali mengalami penurunan sebesar $1,25 \%$ ke angka $127,81 \%$ namun tetap berada di kriteria sangat efektif.

Peningkatan perolehan Pajak Daerah oleh pemerintah daerah dengan rentang waktu 20092014 menunjukan posisi yang cenderung fluktuatif dengan pencapaian tingkat efektivitas terbesar berada pada tahun 2012 dengan angka $129,67 \%$. Analisis dan perhitungan rasio diatas mendukung dan membuktikan asumsi tentang konidisi pencapaian Pajak Daerah yang cenderung fluktuatif (naik dan turun) serta ketertarikan peneliti yang ingin mengetahui tingkat efektivitasnya dan memberikan gambaran kepada masyarakat khususnya masyarakat Kabupaten Bantul untuk 
mengetahui kondisi PAD dalam hal ini Pajak Daerah.

\section{Analisis Data Efisiensi Pajak Daerah}

Efisiensi pajak daerah adalah nilai yang dihitung berdasarkan presentase biaya pemungutan pajak dibagi realisasi penerimaan Pajak Daerah.

Rasio Efisiensi Pajak Daerah:

$\frac{\text { B. Pen. Pajak Daerah } *}{\text { Penerimaan Pajak Daerah }} X 100 \%$

*Biaya Penerimaan Pajak Daerah

Kriteria yang digunakan dalam menilai efisiensi Pajak Daerah adalah pengelolaan pajak daerah dikatakan efisien apabila rasio efisiensi atau rasio biaya pungut tidak melebihi 5\% Keputusan Menteri Dalam Negeri No. 35 Tahun 2002 dikutip dalam Puspitasari (2014). Bahri F (2011) mangatakan untuk mengukur tingkat efisiensi pemungutan Pajak Daerah adalah dengan membandingkan biaya untuk memperoleh Pajak Daerah dengan hasil perolehan Pajak Daerah.

Tabel 7. Realisasi Pajak Daerah dan Biaya/Belanja

DPPKAD Kabupaten Bantul periode 2009-2014 (dalam rupiah)

\begin{tabular}{ccc}
\hline Tahun & Realisasi & Biaya/Belanja \\
\hline 2009 & 14.108 .451 .478 & 43.319 .634 .903 \\
2010 & 16.541 .249 .955 & 16.529 .292 .901 \\
2011 & 35.068 .591 .776 & 29.964 .757 .202 \\
2012 & 51.768 .352 .231 & 32.634 .465 .618 \\
2013 & 83.232 .017 .500 & 41.968 .267 .212 \\
2014 & 99.558 .470 .705 & 58.532 .516 .393
\end{tabular}

Sumber : DPPKAD Kab. Bantul, data diolah

Rasio Efisiensi Pajak Daerah $=\frac{\text { Biaya Penerimaan Jajak Daerah }}{\text { 摨enerimaan Pajak Daerah }} \times 100 \%$

Tabel 8. Perhitungan Efisiensi Pajak Daerah DPPKADKabupaten Bantul periode 20092014(dalam rupiah)

\begin{tabular}{ccccc}
\hline Tahun & Reaslisasi & Biaya/Belanja & Persentase & Kriteria \\
\hline 2009 & 14.108 .451 .478 & 43.319 .634 .903 & $307,04 \%$ & Tidak Efisien \\
2010 & 16.541 .249 .955 & 16.529 .292 .901 & $99,92 \%$ & Kurang Efisien \\
2011 & 35.068 .591 .776 & 29.964 .757 .202 & $85,44 \%$ & Cukup Efisien \\
2012 & 51.768 .352 .231 & 32.634 .465 .618 & $63,03 \%$ & Efisien
\end{tabular}




\section{$2013 \quad 83.232 .017 .500 \quad 41.968 .267 .212 \quad 50,42 \% \quad$ Sangat Efisien \\ $2014 \quad 99.558 .470 .705 \quad 58.532 .516 .393 \quad 58,79 \% \quad$ Sangat Efisien}

Sumber : DPPKAD Kab. Bantul, data diolah

Tabel 8 menunjukan tingkat pencapaian pemerolehan Pajak Daerah dengan tingkat efisiensi tahun 2009 adalah yang teringgi dalam tahun 2009-2014 yakni dengan tingkat persentase sebesar 307,04\% atau dalam kata lain biaya pemerolehan Pajak Daerah tahun ini menggunakan anggaran 30,704 kali lipat dari Pajak Daerah yang dihasilkan, tidak efisien. Tahun 2010 tingkat efisiensi di angka 99,92\% dengan kategori kurang efisien, turun sebesar 207,12\%. Tingkat persentase efisiensi pemerolehan Pajak Daerah tahun 2011 masuk kategori cukup efisien mencapai angka 85,44\% turun dari persentase sebelumnya sebesar 14,48\%. Untuk tahun 2012 dinyatakan efisien, angka persentase efisiensi Pajak Daerah sebesar $63,03 \%$, selisih turun dari tahun sebelumnya $22,41 \%$. Efisiensi pencapaian pemerolehan Pajak Daerah tahun 2013 dengan efisiensi $50,42 \%$, angka ini adalah yang terendah dalam periode 2009-2014, dan dinyatakan sangat efisien, persentasenya turun sebesar $12,61 \%$ dari tahun sebelumnya. Sedangkan efisiensi perolehan Pajak Daerah tahun 2014 kembali naik dari tahun sebelumnya sebesar $8,37 \%$ di angka $58,79 \%$. namun tetap dalam kategori sangat efisien.
Secara keseluruhan, efisiensi pemerolehan Pajak Daerah Kabupaten Bantul berkinerja baik dengan hasil tren yang terus turun di periode 2009-2014, dari besaran angka $300,04 \%$ pada tahun 2009 turun ke angka $58,79 \%$ pada tahun 2014 yang mana angka tersebut memenuhi kriteria/kategori sangat efisien.

\section{Analisis Data Efektivitas Retribusi Daerah}

Untuk menganalisis kinerja administrasi Retribusi Daerah, perlu dihitung efektivitas pemungutan efektivitas Retribusi Daerah, dimana secara umum efektivitas memperlihatkan seberapa besar pendapatan retribusi dibandingkan dengan potensi Retribusi Daerah sebenarnya. Target retribusi yaitu suatu jumlah yang telah ditentukan dan harus dicapai selama setahun anggaran dan potensi penerimaan retribusi yaitu usaha untuk menaikan retribusi untuk mencapai target (Rosa, 2012). Efektivitas retribusi daerah merupakan perbandingan antara realisasi dan target penerimaan retribusi daerah, sehingga dapat digunakan sebagai ukuran keberhasilan dalam melakukan pungutan (Puspitasari, 2014).

Tabel 9. Realisasi Retribusi Daerah dan TargetKabupaten Bantul Periode 2009-2014 (dalam rupiah)

\begin{tabular}{ccc}
\hline Tahun & Terget Retribusi Daerah & Realisasi \\
\hline 2009 & 48.219 .832 .144 & 58.205 .951 .445 \\
2010 & 14.676 .656 .244 & 15.978 .422 .097 \\
2011 & 18.791 .093 .190 & 17.798 .603 .458 \\
2012 & 19.821 .987 .200 & 20.595 .098 .751 \\
c2013 & 26.671 .104 .494 & 27.116 .286 .436 \\
2014 & 26.490 .454 .741 & 26.004 .713 .221 \\
\hline
\end{tabular}

Sumber : DPPKAD Kab. Bantul, data diolah 
Tabel 10.Perhitungan Efektivitas Retribusi DaerahKabupaten Bantul Periode 2009-2014

(dalam rupiah)

\begin{tabular}{rcccc}
\hline Tahun & Terget & Realisasii & Efektivitas & Ktriteria \\
\hline 2009 & 48.219 .832 .144 & 58.205 .951 .445 & $120,70 \%$ & SangatEfektif \\
2010 & 14.676 .656 .244 & 15.978 .422 .097 & $108,86 \%$ & Sangat Efektif \\
2011 & 18.791 .093 .190 & 17.798 .603 .458 & $94,71 \%$ & Efektif \\
2012 & 19.821 .987 .200 & 20.595 .098 .751 & $103,90 \%$ & Sangat Efektif \\
2013 & 26.671 .104 .494 & 27.116 .286 .436 & $101,66 \%$ & Sangat Efektif \\
2014 & 26.490 .454 .741 & 26.004 .713 .221 & $98,16 \%$ & Efektif
\end{tabular}

Sumber : DPPKAD Kab. Bantul, data diolah

Pada tabel 9 dan tabel 10, berdasarkan rasio efektivitas diperoleh hasil efektivitas pemerolehan Retribusi Daerah tahun 20092014. Tahun 2009 hasil perolehan Retribusi Daerah dinyatakan sangat efektif dengan angka persentase sebesar $120,70 \%$, naik $20,70 \%$ dari target. Tahun 2010 kriteria sanget efektif dengan angka persentase $108,86 \%$, namun turun sebesar $11,84 \%$ dari tahun 2009. Tahun 2011 dinyatakan efektif karena perolehan hanya pada angka $94,71 \%$, selisih $14,15 \%$ dari tahun sebelumnya. Tahun 2012 sangat efektif dengan perolehan kembali naik ke angka 103,90\%, selisih naik 9,19\% dari tahun 2011. Perolehan Retribusi Daerah tahun 2013 kembali turun sebesar 2,22\% dari tahun 2012 103,90\% ke angka $101,66 \%$ namun tetap dinyatakan sangat efektif. Tahun 2014 hanya mampu terealisasi di angka efektivitas $98,16 \%$, pencapaian ini masuk kriteria efektif. Perolehan tahun 2014 turun sebesar 3,5\% dari tahun 2013. Hasil dinyatakan bedasarkan kriteria pada tabel kriteria efektivitas.

\section{Analisis Data Efisiensi Retribusi Daerah}

Efisiensi retribusi daerah mengukur besarnya biaya perolehan yang digunakan terhadap realisasi penerimaan retribusi itu sendiri (Puspitasari, 2014). Rasio Efisiensi menggambarkan efisiensi pengeluaran biaya dalam merealisasikan PAD yang direncanakan dibandingkan dengan target yang ditetapkan berdasarkan potensi rill. Pengujian efisiensi ini bertujuan untuk mengetahui dan memberikan gambaran tentang kondisi pemungutan Retribusi Daerah di Kabupaten Bantul. Perbandingan antara realisasi penerimaan Retribusi Daerah dengan total biaya/belanja langsung dan tidak langsung dari dinas, kantor, dan badan penghasil retribusi di Kabupaten Bantul.

Tabel 11. Realisasi Retribusi Daerah dan Total BelanjaDinas PenghasilKabupaten Bantul Periode 2009-2014(dalam rupiah)

\begin{tabular}{ccc}
\hline Tahun & $\begin{array}{c}\text { Realisasi Retribusi } \\
\text { Daerah }\end{array}$ & $\begin{array}{c}\text { Total Belanja Dinas } \\
\text { Penghasil }\end{array}$ \\
\hline 2009 & 58.205 .951 .445 & 116.929 .275 .568 \\
2010 & 15.978 .422 .097 & 210.413 .329 .069 \\
2011 & 17.798 .603 .458 & 280.332 .123 .549 \\
2012 & 20.595 .098 .751 & 356.518 .564 .583
\end{tabular}




\begin{tabular}{lll}
2013 & 27.116 .286 .436 & 429.549 .545 .642 \\
2014 & 26.004 .713 .221 & 441.073 .706 .510 \\
\hline
\end{tabular}

Sumber : DPPKAD Kab. Bantul, data diolah

Rasio Efisiensi Retribusi $=\frac{\text { Biaya Penerimaan Retribusi Daerah }}{\text { Penerimaan Retribusi Daerah }} X 100 \%$

Tabel 12.Perhitungan Efisiensi Retribusi Daerah Kabupaten Bantul Periode 2009-2014 (dalam rupiah)

\begin{tabular}{cccc}
\hline Tahun & Reaslisasi & $\begin{array}{c}\text { Total Belanja } \\
\text { Dinas Penghasil }\end{array}$ & \multicolumn{1}{c}{ Efisiensi } \\
\hline 2009 & 58.205 .951 .445 & 116.929 .275 .568 & $200,88 \%$ \\
2010 & 15.978 .422 .097 & 210.413 .329 .069 & $1.316,85 \%$ \\
2011 & 17.798 .603 .458 & 280.332 .123 .549 & $1.575,02 \%$ \\
2012 & 20.595 .098 .751 & 356.518 .564 .583 & $1.731,08 \%$ \\
2013 & 27.116 .286 .436 & 429.549 .545 .642 & $1.584,10 \%$ \\
2014 & 26.004 .713 .221 & 441.073 .706 .510 & $1.696,12 \%$ \\
\hline
\end{tabular}

Sumber : DPPKAD Kab. Bantul, data diolah

Dari tabel 11 dan penerapan rumus efisiensi serta tabel 12 menjelaskan tentang tingkat yang sangat kurang efisiensi, data tahun 2009-2014 secara keseluruhan melebihi angka $100 \%$ dimulai dari $200,88 \%$ di tahun 2009 , $1.316,85 \%$ untuk tahun $2010,1.575,02 \%$ di tahun 2011, $1.731,08 \%$ di tahun 2012, $1.584,10 \%$ untuk perbandingan biaya/belanja pada dinas penghasil untuk tahun 2013, dan angka 1.696,12\% untuk tahun 2014. Tahun 2012 adalah tahun tertinggi tingkat sangat kurang efisien untuk perolehan Retribusi Daerah dilingkungan Kabupaten Bantul. Secara keseluruhan pemerolehan Retribusi Daerah dinyatakan sangat tidak efisien, karena berada pada angak di atas $100 \%$ sesuai dengan tabel kriteria.

\section{Tabel 13. Selisih Total Anggaran \\ Periode 2009-2014 \\ (dalam rupiah)}

\begin{tabular}{ccc}
\hline Tahun & $\begin{array}{c}\text { Total Belanja Dinas } \\
\text { Penghasil }\end{array}$ & Selisih Anggaran \\
\hline 2009 & 116.929 .275 .568 & 93.484 .053 .501 \\
2010 & 210.413 .329 .069 & 69.918 .794 .480 \\
2011 & 280.332 .123 .549 & 76.186 .441 .034 \\
2012 & 356.518 .564 .583 & 73.030 .981 .059
\end{tabular}




$$
\begin{array}{lll}
2013 & 429.549 .545 .642 & 11.524 .160 .868 \\
2014 & 441.073 .706 .510 & 324.144 .430 .942
\end{array}
$$

Sumber : DPPKAD Kab. Bantul, data diolah

Lebih lanjut, tabel 13 menunjukan selisih anggaran belanja langsung dan tidak langsung dari tahun 2010 ke 2009 sebesar 93.484.053.501; tahun 2011 ke 2010 sebesar 69.918.794.480; 2012 ke 2011 selisih dengan jumlah 76.186.441.034; sementara tahun 2013 ke 2012 meningkat sebesar 73.030.981.059; kemudian tahun 2014 ke 2013 sebesar 11.524.160.868; dan tahun 2014 ke 2009 memiliki selisih angka dengan jumlah besar yakni 324.144.430.942.

Peningkatan biaya/belanja yang dikeluarkan pemerintah daerah dalam upaya dan usaha memperoleh Retribusi Daerah. Tingkat persentase efisiensi Retribusi Daerah yang besar disebabkan penerapan perbandingan biaya/belanja yang terintegrasi antara langsung dan tidak langsung. Meningkatnya angka selisih (naik) anggaran biaya/belanja dapat diartikan dua hal, pertama adalah sebagai bentuk ketidakefisienan pemerintah Kabupaten Bantul dalam melakukan fungsi daerah untuk memungut Retribusi Daerah yang tidak menutup biaya pemerintah untuk menyelenggarakan pemberian jasa kepada orang pribadi atau badan yang mendapatkan suatu keistimewaan yang diberikan pemerintah daerah, kedua besaran anggaran tersebut adalah bentuk investasi pemerintah Kabupaten Bantul untuk meningkatkan sumber-sumber penerimaan daerah di masa mendatang.

\section{Analisis Data Kontribusi Pajak Daerah terhadap PAD}

Analisis kontribusi digunakan untuk mengetahui seberapa besar peranan seluruh penerimaan daerah (Pajak Daerah dan Retribusi Daerah) dalam meningkatkan PAD, sehingga dengan adanya data tersebut dapat memberikan gambaran yang jelas mengenai tindakan atau kebijakan yang harus dilakukan pemerintah daerah dalam usaha meingkatkan peran seluruh penerimaan daerah tersebut (Mikha, 2010). Analisis data kontribusi Pajak Daerah diterapkan dengan tujuan menjawab rumusan masalah serta untuk mengetahui besaran kontribusi Pajak Daerah terhadap PAD Kabupaten bantul, adapun penerapan tersebut sebagai berikut :

\section{Tabel 14. Realisasi Pajak Daerah dan Total PAD Kabupaten Bantul} Periode 2009-2014 (dalam rupiah)

\begin{tabular}{ccc}
\hline Tahun & Reaslisasi & Total PAD \\
\hline 2009 & 14.108 .451 .478 & 88.691 .362 .690 \\
2010 & 16.541 .249 .955 & 81.646 .839 .293 \\
2011 & 35.068 .591 .776 & 128.896 .456 .173 \\
2012 & 51.768 .352 .231 & 166.597 .778 .028 \\
2013 & 83.232 .017 .500 & 224.197 .857 .443 \\
2014 & 99.558 .470 .705 & 357.271 .829 .724
\end{tabular}

Sumber : DPPKAD Kab. Bantul, data diolah 


$$
\text { Rumus Kontribusi Pajak Daerah }=\frac{\text { 捦ajak Daerah }}{\text { Realisasi PAD }} X 100 \%
$$

Tabel 15. Realisasi Pajak Daerah, Total PAD, dan KontribusiKabupaten Bantul Periode 2009-2014 (dalam rupiah)

\begin{tabular}{ccccc}
\hline Tahun & Reaslisasi & Total PAD & Kontribusi & Kriteria \\
\hline 2009 & 14.108 .451 .478 & 88.691 .362 .690 & $15,90 \%$ & Kurang \\
2010 & 16.541 .249 .955 & 81.646 .839 .293 & $20,25 \%$ & Sedang \\
2011 & 35.068 .591 .776 & 128.896 .456 .173 & $27,20 \%$ & Sedang \\
2012 & 51.768 .352 .231 & 166.597 .778 .028 & $31,07 \%$ & Cukup Baik \\
2013 & 83.232 .017 .500 & 224.197 .857 .443 & $37,12 \%$ & Cukup Baik \\
2014 & 99.558 .470 .705 & 357.271 .829 .724 & $27,86 \%$ & Sedang
\end{tabular}

Sumber : DPPKAD Kab. Bantul, data diolah

Realisasi pemungutan Pajak Daerah tahun 2009 oleh pemerintah daerah Kabupaten Bantul dengan jumlah 14.108.451.478 berkontribusi sebesar $15,90 \%$ terhadap PAD, periode ini kriteria kurang; tahun 2010, jumlah realisasi 16.541.249.955 berkontribusi sebesar $20,25 \%$ dari 81.646.839.293, mengalami kenaikan sebesar 4,35\%, dan masuk kriteria sedang; tahun 2011, total perolehan Pajak Daerah menyumbang porsi sebesar 35.068.591.776 atau $27,20 \%$ dari angka total PAD 128.896.456.173, naik 6,95\% dari tahun sebelumnya, kriteria sedang; 2012 juga mengalami kenaikan besaran jumlah Pajak Daerah yang terpungut yaitu 51.768.352.231 atau $31,07 \%$ dari 166.597.778.028, naik 3,87\%, periode tahun ini masuk kriteria cukup baik; tahun 2013, angka realisasi Pajak Daerah 83.232.017.500 menyumbang $37,12 \%$ dari 224.197.857.443 total PAD, naik 6,05\%, angka sumbangan Pajak Daerah ini masih memenuhi kriteria cukup baik; tahun 2014 tetap mengalami kenaikan dalam angka jumlah total perolehan Pajak Daerah dengan kontribusi sebesar 99.558.470.705 dari total angka jumlah total PAD 357.271.829.724, dalam hal Persentase, tahun 2014 mengalami penurunan sebesar 9,26\% dari $37,12 \%$ ke $27,86 \%$, selaras dengan penurunan, kriteria kontribusi pajak periode ini turun ke predikat sedang. Tahun 2013 adalah tahun dengan tingkat kontribusi Pajak Daerah yang tertinggi dalam kurun waktu 2009-2014.

\section{Analisis Data Kontribusi Retribusi Daerah terhadap PAD}

Kontribusi dapat diartikan sebagai sumbangan yang dibeikan oleh retribusi terhadap penerimaan PAD (Supriadi dkk, 2015). Mulyanto dalam Mikha (2010) mengatakan analisi kontribusi Pajak Daerah dan Retribusi Daerah digunakan untuk mengetahui jumlah kontribsui yang berikan terhadap PAD, Mikha sendiri mengatakan kontribusi Retribusi Daerah merupakan rasio antara realisasi penerimaan dari Retribusi Daerah dalam $t$ tahun dengan realisasi penerimaan PAD pada tahun yang sama, analisis kontribusi Retribusi Daerah digunakan untuk mengetahui seberapa besar peranan penerimaan Retribusi Daerah dalam meningkatkan PAD. Rumus dan pembahasan, sebagai berikut : 
Tabel 16.Realisasi Retribusi Daerah dan Total PAD Kabupaten Bantul

Periode 2009-2014 (dalam rupiah)

\begin{tabular}{ccc}
\hline Tahun & Reaslisasi & Total PAD \\
\hline 2009 & 58.205 .951 .445 & 88.691 .362 .690 \\
2010 & 15.978 .422 .097 & 81.646 .839 .293 \\
2011 & 17.798 .603 .458 & 128.896 .456 .173 \\
2012 & 20.595 .098 .751 & 166.597 .778 .028 \\
2013 & 27.116 .286 .436 & 224.197 .857 .443 \\
2014 & 26.004 .713 .221 & 357.271 .829 .724
\end{tabular}

Sumber : DPPKAD Kab. Bantul, data diolah

Rumus Kontribusi Ret 搜ibusi Daerah $=\frac{\text { Retribusi Daerah }}{\text { Realisasi Penerimaan Asli Daerah }} X 100 \%$

Tabel 17.Perhitungan Kontribusi Retribusi DaerahKabupaten Bantul Periode 2009-2014 (dalam rupiah)

\begin{tabular}{ccccc}
\hline Tahun & Reaslisasi & TotalPAD & Kontribusi & Kriteria \\
\hline 2009 & 58.205 .951 .445 & 88.691 .362 .690 & $65,62 \%$ & Sangat Baik \\
2010 & 15.978 .422 .097 & 81.646 .839 .293 & $19,57 \%$ & Kurang \\
2011 & 17.798 .603 .458 & 128.896 .456 .173 & $13,80 \%$ & Kurang \\
2012 & 20.595 .098 .751 & 166.597 .778 .028 & $12,36 \%$ & Kurang \\
2013 & 27.116 .286 .436 & 224.197 .857 .443 & $12,09 \%$ & Kurang \\
2014 & 26.004 .713 .221 & 357.271 .829 .724 & $7,27 \%$ & Sangat Kurang \\
\hline
\end{tabular}

Sumber : DPPKAD Kab. Bantul, data diolah

Perolehan Retribusi Daerah tahun 2009 oleh pemerintah daerah Kabupaten Bantul dengan jumlah 58.205.951.445 berkontribusi sebesar $65,62 \%$ terhadap PAD, sangat baik; tahun 2010, jumlah realisasi 15.978.422.097 berkontribusi sebesar $19,57 \%$ dari 81.646.839.293, mengalami penurunan drastis sebesar $46,05 \%$, merupakan penurunan terbesar dari tahun 2009-2014, dengan kriteria kontribusi kurang; tahun 2011, total perolehan Retribusi Daerah menyumbang porsi sebesar 17.798.603.458 atau $13,80 \%$ dari angka total PAD 128.896.456.173, turun 5,77\% dari tahun sebelumnya, kriteria kurang; 2012 juga mengalami penurunan, besaran jumlah Retribusi Daerah yang terpungut yaitu 20.595.098.751 atau $12,36 \%$ dari 166.597.778.028, turun lagi sebesar $1,44 \%$, masih dengan kriteria kurang.

Tahun 2013, angka realisasi Retribusi Daerah 27.116.286.436 menyumbang 12,09\% dari 224.197.857.443 total PAD, kembali turun sebesar 0,27\%, kontribusi dengan kriteria kurang; tahun 2014 mengalami penurunan dalam angka jumlah total perolehan Retribusi Daerah dengan kontribusi sebesar 26.004.713.221 dari total angka jumlah total 
PAD 357.271.829.724, dengan Persentase angka $7,27 \%$ atau turun sebesar $4,97 \%$, penurunan kontribusi periode ini masuk kriteria sangat kurang. Secara keseluruhan, dalam rentang waktu 2009-2014, perolehan Retribusi Daerah oleh pemerintah Kabupaten Bantul mengalami penurunan dengan sifat penurunan pendapatan dari tahun 2009 sebesar $65,62 \%$ ke tahun 2010 dan terus turun hingga ke 7,27\% pada tahun 2014 yang merupakan kontribusi terendah dalam kurun waktu tersebut.

Efektivitas dan kontribusi Pajak serta Retribusi Daerah kiranya dapat ditingkatkan untuk mendukung kemandirian pemerintah daerah dalam hal finansial. Khusus efisiensi, merujuk pada transparansi keuangan instansi pemerintah maka perlu dilakukan pembukuan yang memisahkan antara kegiatan produktif retribusi dan kegiatan pembangunan oleh pemerintah daerah.

\section{PENUTUP}

\section{Kesimpulan}

Berdasarkan hasil penelitian dan pembahasan Efektivitas Pajak Daerah, Efisiensi Retribusi Daerah, Kontribusi Pajak Daerah, dan Kontribusi Retribusi Daerah terhadap Pendapatan Asli Daerah pada Kabupaten Bantul 2009-2014 (studi kasus pada DPPKAD Kabupaten Bantul) di bagian sebelumnya yang disesuaikan dengan Undang-undang dan Peraturan Daerah Kabupaten Bantul yang berlaku serta memperhatikan kebutuhan penulis, maka dapat diambil kesimpulan bahwa :

1. Berdasarkan penelitian dengan rasio efektivitas, tingkat perolehan Pajak Daerah pada Kabupaten Bantul tahun 2009, 2011,2012,2013, dan 2014 dinyatakan sangat efektif meskipun cenderung fluktuatif (naik dan turun), masing-masing besaran persentase $100,56 \%, 113,85 \%, 129,67 \%$, $129,06 \%$, $127,81 \%$, serta tahun 2010, ditingkat efektif sebesar 99,17\%. Tahun 2012 adalah yang tertinggi dan 2010 adalah terendah.Berdasarkan rasio efisiensi, tingkat pemerolehan Pajak Daerah Kabupaten Bantul periode 2009-2014 cenderung naik turun (fluktuatif) per tahunnya namun keseluruhan mengalami penurunan antara biaya dan pajak yang dihasilkan, tahun 2009 adalah yang tertinggi dan tidak efisien dengan perolehan $307,04 \%$ dan terendah serta sangat efisien adahal tahun 2013 dengan angka $50,42 \%$.

2. Berdasarkan pengujian rasio efektivitas, tingkat pemerolehan Retribusi Daerah secara keseluruhan cenderung baik, tahun 2009 (120,70\%), $2010 \quad(108,86 \%), \quad 2012$ (103,90\%), dan $2013(101,66 \%)$ dinyatakan sangat efektif dengan angka pemerolehan diatas 100\%, sedangkan tahun 2011 $(94,71 \%)$ dan $2014(98,16 \%)$ dinyatakan efektif. Berdasarkan penelitian dengan rasio efisiensi, tingkat efisiensi perolehan Retribusi Daerah berbanding biaya/belanja dalam upaya mendapatan Retribusi Daerah oleh dinas penghasil di Kabupaten Bantul dengan mengacu pada besaran belanja langsung dan tidak langsung dalam kurun waktu 20092014 dinyatakan sangat tidak efisien, masing masing besarannya diatas $100 \%$ yakni 2009 200,88\%, $20101.316,85 \%, 20111.575,02 \%$, $20121.731,08 \%, 20131.584,10 \%$, dan 2014 sebesar $1.696,12 \%$. Tahun 2009 adalah yang terendah dan 2012 adalah yang tertinggi.

3. Berdasarkan penelitian dengan rasio kontribusi, tingkat kontribusi Pajak Daerah terhadap PAD Kabupaten Bantul cenderung fluktuatif (naik dan turun), pada tahun 2009 dinyatakan kurang dengan berada di posisi 15,90\%, tahun 2010, 2011, 2011, dan 2014 berada pada posisi sedang dengan besaran masing-masing $20,25 \%, 27,20 \%$, dan 27,86\%. Tahun 2012 serta 2013 berada pada posisi $31,07 \%$ dan $37,12 \%$. Tahun 2013 adalah yang terbesar dan 2009 terendah.

4. Berdasarkan penelitian dengan rasio kontribusi, tingkat kontribusi Retribusi Daerah Terhadap PAD Kabupaten Bantul relatif mengalami penurunan dari tahun 2009 sebesar 65,62\% ke tahun 2014 sebesar $7,27 \%$, kedua tahun ini dinyatakan yang tertinggi dan terendah. Tahun 2010 kontribusi hanya sebesar $19,57 \%$, kembali penurunan tahun 2011 di posisi 13,80\%, 2011 12,36\%, tahun 2013 sebesar 12,09\%.

\section{Implikasi Penelitian}

Berdasarkan kesimpulan hasil penelitian yang telah dikemukakan tersebut,implikasi dari 
hasil penelitian adalah sebagai berikut: Pajak Daerah adalah Pungutan dan/atau sumbangan wajib yang tidak berimbal atas penyerahannya, Pajak Daerah dilaksanakan oleh pemerintah daerah kepada masyarakatnya sebagai sumber keuangan untuk operasional pemerintahan dan pembangunan daerah serta untuk kemakmuran penduduk diwilayahnya. Retribusi Daerah bisa disebut juga sebagai imbalan yang ditarik oleh pemerintah daerah atas penyediaan, pemberian layanan jasa kepada orang pribadi atau badan (pembayar/pengguna jasa) yang memberikan nilai dan manfaat lebih bagi pihak pembayar.

Bagi pemerintah, adanya penelitian diharapkan mampu memberikan acuan untuk meningkatkan efektivitas perolehan Pajak Daerah dan Retribusi Daerah dengan tetap memperhatikan asas-asas pemungutan Pajak serta tingkat efisiensi untuk upaya permerolehan Retribusi Daerah.

\section{Keterbatasan Penelitian}

Penyusunan penelitian ini menemui beberapa kendala yang menyebabkan pengaruh besar pada hasil dan pembahasan. Ada pun kendala-kendala tersebut adalah pertama, penelitian di lakukan bersamaan dengan periode pemerintah daerah untuk mempersiapkan laporan keuangan dan keperluan lain untuk pemeriksaan Badan Pemeriksa Keuangan, hal ini mengakibatkan peneliti mengalami sedikit kendala dalam usaha mengumpulkan data. Kedua, tidak adanya pengadministrasian yang secara rinci atau terpisah untuk kegiatan belanja pemerintah daerah baik itu pegawai, peralatan, dan perlengkapan kantor yang secara langsung berhubungan dengan usaha pemerintah daerah dalam meningkatkan pendapatan asli darah dari kegiatan pemerintah dalam melakukan kewajiban lain dalam pelayanan masyrakat dan kegiatan pembangunan daerah di Kabupaten Bantul. Karena keadaan tersebut, maka peneliti melakukan penelitian dengan menggunakan belanja langsung dan tidak langsung dari setiap dinas penghasil PAD dalam hal ini Retribusi Daerah. Namun, meskipun sebagai sumber keuangan yang sah pada Kabupaten Bantul, Retribusi tidak terlalu memberikan kontribusi yang lebih baik dari Pajak Daerah dan relatif menurun.

\section{Saran}

Berdasarkan hasil pembahasan penelitian dan kesimpulan di atasmaka dapat diberikan saran-saran sebagai berikut:

1. Bagi Pemerintah Daerah Kabupaten Bantul

a. Tingkat pecapaian Pajak Daerah atas target yang selalu meningkat sudah sangat baik/efektif, namun tetap memperhatikan konsistensi yang selaras dengan tren persentesenya karena terlihat naik dan turun (fluktuatif), serta kontribusinya perlu ditingkatkan. Perlu diadakan upaya-upaya untuk meningkatkan hasil PAD khususnya Pajak Daerah dan Retribusi Daerah. Penurunan perolehan PAD dari sektor Retribusi Daerah kiranya mendapatkan perhatian serius, evaluasi, dan ditingkatkan semaksimal mungkin karena tren kontribusi yang terus turun.

b. Dengan adanya penelitian ini, pemerintah daerah diharapkan melakukan pengadministrasian terpisah dan terperinci untuk kegiatan belanja pemerintah daerah dalam upaya untuk memperoleh pendapatan dengan kegiatan lainnya yang tidak berhubungan dengan upaya tersebut. Pemisahan tersebut berujuan untuk memudahkan proses evaluasi dan memberikan fungsi kontrol serta membantu pemerintah daerah khususnya Dinas Pendapatan, Pengelolaan Keuangan dan Aset Daerah Kabupaten Bantul untuk mencapai sasaran huruf (a) Meningkatnya efisiensi, eketifitas dan responsibilitas pelayanan publik.

2. Bagi Peneliti Selanjutnya

Penelitian ini membahas secara umum gambaran tentang efektivitas Pajak Daerah, Efisiensi Retribusi Daerah, Kontribusi Pajak Daerah, dan Kontribusi Retribusi Daerah terhadap PAD. Adanya keterbatasan dalam penelitian ini, maka diharapkan kepada peneliti selanjutnya untuk dapat melakukan penelitian secara mendalam dan berfokus pada upaya dan hasil serta belanja pemerintah daerah dalam usaha memperoleh pendapatan dari Retribusi 
Daerah untuk dapat digeneralisasikan pada wilayah lain yang lebih luas.

\section{DAFTAR PUSTAKA}

Ardhiansyah, Diaz., Rahayu, Sri Mangesti., dan Husaini, Achmad. 2014. Analisis Potensi Pajak Hotel dan Pajak Restoran dan Kontribusinya Terhadap Pendapatan Asli Daerah (PAD) (Studi Kasus pada Dinas Pendapatan Daerah Kota Batu Tahun 2011-2013) Fakultas Ilmu Administrasi Universitas Brawijaya Malang. Jurnal Administrasi Bisnis (JAB)|Vol. 14 No. 1 September 2014.

Aryani, Farida. 2015. Analisis Pertumbuhan serta Efektivitas dan Efisiensi Pemungutan Pajak Daerah Kabupaten Musi Banyuasin.Dosen PNS Kopertis Wilayah II dpk pada STIE Rahmaniyah Sekayu.

Bahri F, M Samsul. 2011. Efisiensi dan Efektivitas Pemungutan Pajak Daerah Kota Surakarta Tahun 2004-2009. Skripsi Strata Satu Fakultas Keguruan dan Ilmu Pendidikan Universitas Sebelas Maret.

Dinas Pendapatan, Pengelolaan Keuangan dan Aset Daerah Kabupaten Bantul, 2016. Sumber Data Daftar Target dan Realisasi Pendapatan Daerah Tahun 2009.

2016. Sumber Data Daftar Target dan Realisasi Pendapatan Daerah Tahun 2010. 2016. Sumber Data Daftar Target dan Realisasi Pendapatan Daerah Tahun 2011.

Dinas Pendapatan, Pengelolaan Keuangan dan Aset Daerah Kabupaten Bantul, 2016. Sumber Data Daftar Target dan Realisasi Pendapatan Daerah Tahun 2012.

2016. Sumber Data Daftar Target dan Realisasi Pendapatan Daerah Tahun 2013.
2016. Sumber Data Daftar Target dan Realisasi Pendapatan Daerah Tahun 2014.

Dinas Pendapatan, Pengelolaan Keuangan dan Aset Kabupaten Bantul. http://dppkad.bantulkab.go.id Copyright 2016 (C) Kantor PDT Pemerintah Kabupaten Bantul (Di akses pada tanggal 4 Januari 2016 sebagai sumber acuan data dan informasi tentang Dinas Pendapatan, Pengelolaan Keuangan dan Aset Daerah Kabupaten Bantul)

Doru, Yakobus. 2014. Analisis Kontribusi Penerimaan Pajak Daerah, Retribusi Daerah dan Lain-lain Pendapatan Asli Daerah yang Sah Terhadap Pendapatan Asli Daerah. Skripsi Strata Satu Fakultas Ekonomi Jurusan Akuntansi Universitas Sarjanawiyata Tamansiswa Yogyakarta.

Fauziah, Isfatul., Husaini, Achmad., Shobaruddin, M. 2014. Analisis Kontribusi Penerimaan Pajak Daerah sebagai Salah Satu Sumber Pendapatan Asli Daerah (PAD) Kabupaten Malang (Studi Pada Dinas Pendapatan Pengelolaan Keuangan dan Aset Kabupaten Malang). Jurnal PerPajakan | Vol. 3 No. 1 Desember 2014| Universitas Brawijaya Malang.

Hakim, Vita Amaliah. 2013. Analisis Efektivitas dan Efisiensi Pajak Daerah dan Retribusi Daerah Terhadap Pendapatan Asli Daerah Kota Tasikmalaya (Studi Kasus Pada Dinas Pendapatan Kota Tasikmalaya) Program Studi Akuntansi Fakultas Ekonomi. Universitas Siliwangi

Handoko, Sri P, SE. 2013. Analisis Tingkat Efektivitas Pajak Daerah Sebagai Sumber Pendapatan Daerah Kota Pontianak. Jurnal Ilmiah Program Magister Ilmu Ekonomi Universitas Tanjungpura, Pontianak 2013.

Julastiana, Yaneka., Suartana, Iwayan. 2013. Analisis Efisiensi dan Efektivitas Penerimaan Pendapatan Asli Daerah Kabupaten Klungkung. Fakultas 
Ekonomi Universitas Udayana (Unud), Bali, Indonesia.

Lalityasari, Ayu Rahajeng., Suhadak., Zahroh, Z.A. 2013. Efek Pajak Hotel dan Pajak Restroran Sebagai Sumber Pendapatan Pajak Daerah Kota Batu (Studi Pada Dinas Pendapatan Kota Batu). PS PerPajakan, Jurusan Administrasi Bisnis, Fakultas Ilmu Administrasi, Universitas Brawijaya Malang.

Mikha, Danied. 2010. Analisis Kontribusi Pajak dan Retribusi Daerah terhadap Pendapatan Asli Daerah Kabupaten Sleman. Alumni UPN "Veteran" Yogyakarta. Kajian Akuntansi, Volume 5, Nomor 1, Juni 2010.

Nugroho, Adi. 2014. Analisis Pengaruh Pajak Daerah dan Retribusi Daerah terhadap Pendapatan Asli Daerah (PAD) Kabupaten/Kota di Provinsi Jawa Tengah Periode 2010-2012. Universitas Dian Nuswantoro.

Octovido, Irsandy., Sudjana, Nengah., Azizah, Devi Farah. 2014. Analisis Efektivitas dan Kontribusi Pajak Daerah Sebagai Sumber Pendapatan Asli Daerah Kota Batu (Studi Pada Dinas Pendapatan Daerah Kota Batu Tahun 2009-2013). Fakultas Ilmu Administrasi Universitas Brawijaya Malang | Jurnal Administrasi Bisnis (JAB) | Vol. 15 No. 1 Oktober 2014.

Pajak Daerah dan Retribusi Daerah Kabupaten Bantul.www.jdih.setjen.kemendagri.go. id/files(Di akses pada tanggal 4 Januari 2016 sebagai referensi acuan sumber hukum tentang Pajak Daerah dan Retribusi Daerah Kabupaten Bantul)

Prameka, Adelia Shabrina dkk. 2012. Kontribusi Pajak Daerah dan Retribusi Daerah Terhadap Pendapatan Asli Daerah (PAD) Kabupaten Malang (Studi Pada Dinas Pendapatan Pengelolaan Keuangan dan Aset Kabupaten Malang). Fakultas Ekonomi dan Bisnis Universitas Brawijaya Malang.
Puspitasari, Elfayang Rizky Ayu. 2014. Analisis Efektivitas, Efisiensi, dan Kontribusi Pajak Daerah dan Retribusi Daerah terhadap PAD Kabupaten Blora Tahun 2009-2013. Skripsi Strata satu (S1) pada Program Sarajana Fakultas Ekonomi Universitas Diponegoro Semarang.

Riduansyah, Mohammad. 2003. Kontribusi Pajak Daerah dan Retribusi Daerah terhdapa Pendapatan Asli Daerah (PAD) dan Anggaran Pendapatan dan Belanja Daerah (APBD) guna Mendukung Pelaksanaan Otonomi Daerah (Studi Kasus Pemerintah Daerah Kota Bogor). Makara, Sosial Humaniora, Vol. 7 No. 2, Desember 2003.

Rosa, Yenni Del., 2012. Analisis Efektifitas dan Efisiensi Penerimaan Retribusi Daerah Kabupaten Pesisir Selatan. Dosen Tetap STIE Dharma Andalas.

Safitri, Dian. 2008. Analisis efektivitas, efisiensi dan kontribusi pajak Daerah dalam Upaya Peningkatan Pendapatan Asli Daerah (Studi Kasus pada KPPD Kota Yogyakarta. STIE Nusa Negarakencana.

Sidik, DR. Machfud Msc. 2002. Optimalisasi Pajak Daerah dan Retribusi Daerah Dalam Rangka Meningkatkan Kemampuan Keuangan Daerah. Orasi Ilmiah wisuda XXI STIA LAN Bandung, April Tahun 2002.

Sari, Manasha Rosatia. 2014. Analisis Tingkat Efektivitas Pajak Hiburan di Kabupaten Pasuruan Tahun 20092013. Universitas Negeri Surabaya.

Supriadi, Dara Rizky., Dwiatmanto., Karjo, Suhartini. 2015. Kontribusi Pajak Hiburan Dalam Meningkatkan Pendapatan Asli Daerah (PAD) di Kota Malang (Stidu Kasus Dinas Pendapatan Daerah Kota Malang. PS PerPajakan, Jurusan Administrasi Bisnis, Fakultas Ilmu Administrasi, Universitas Brawijaya Malang. Jurnal 
PerPajakan (JEJAK) | Vol. 1 No. 1

Tahun 2015.

Tope, Patta., dan Darman. 2014. Efektivitas dan Pengelolaan Pendapatan Asli Daerah untuk Menjamin Ketercukupan Kapasitas Fiskal Daerah Otonom Baru Kabupaten Mamuju Utara Provinsi Sulawesi Barat. Fakultas Ekonomi Universitas Tadulako Palu. Jurnal Aplikasi Manajemen | Volume 12 | Nomor 1 | Maret 2014.

Undang-Undang Nomor 34 Tahun 2000. Hukumonline.comhttp://www.hukumon line.com/pusatdata/detail/(diakses tanggal 9 Januari 2016 sebagai referensi Undang-undang).

Undang-Undang Nomor 33 Tahun 2004. Hukumonline.comhttp://www.hukumon line.com/pusatdata/detail/(diakses tanggal 9 Januari 2016 sebagai referensi Undang-undang).

Undang-Undang Nomor 32 Tahun 2004. Hukumonline.comhttp://www.hukumon line.com/pusatdata/detail/(diakses tanggal 9 Januari 2016 sebagai referensi Undang-undang).

Undang-undang No. 28 Tahun 2009. http://www.kemendagri.go.id/produkhukum/2009/09/15/undang-undang-no28-tahun-2009(diakses tanggal 9 Januari 2016 sebagai referensi). 